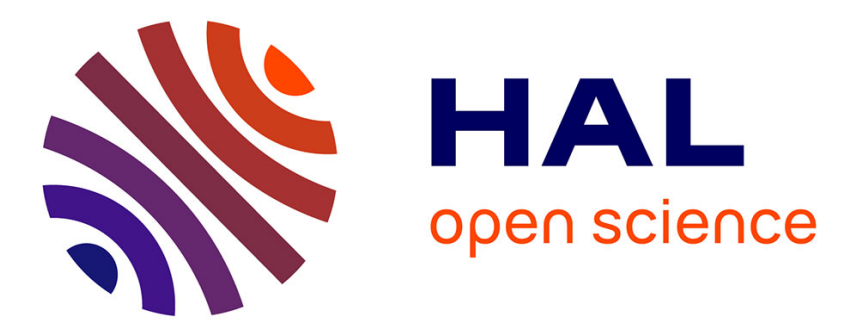

\title{
Studies on a brittle stem mutant of rice, Oryza sativa L. ; characterization of lignin fractions, associated phenolic acids and polysaccharides from rice stem
}

\author{
Umashankar Sharma, Jean-Marc Brillouet, Augustin Scalbert, Bernard
} Monties

\section{To cite this version:}

Umashankar Sharma, Jean-Marc Brillouet, Augustin Scalbert, Bernard Monties. Studies on a brittle stem mutant of rice, Oryza sativa L.; characterization of lignin fractions, associated phenolic acids and polysaccharides from rice stem. Agronomie, 1986, 6 (3), pp.265-271. hal-00884875

\section{HAL Id: hal-00884875 \\ https://hal.science/hal-00884875}

Submitted on 1 Jan 1986

HAL is a multi-disciplinary open access archive for the deposit and dissemination of scientific research documents, whether they are published or not. The documents may come from teaching and research institutions in France or abroad, or from public or private research centers.
L'archive ouverte pluridisciplinaire $\mathbf{H A L}$, est destinée au dépôt et à la diffusion de documents scientifiques de niveau recherche, publiés ou non, émanant des établissements d'enseignement et de recherche français ou étrangers, des laboratoires publics ou privés. 


\title{
Studies on a brittle stem mutant of rice, Oryza sativa L. ; characterization of lignin fractions, associated phenolic acids and polysaccharides from rice stem
}

\author{
Umashankar SHARMA ( $\left.{ }^{a}\right)$, Jean-Marc BRILLOUET, Augustin SCALBERT $\left({ }^{*}\right)$ \& Bernard MONTIES (*b) \\ I.N.R.A., Laboratoire de Biochimie et Technologie des Glucides, rue de la Géraudière, F 44072 Nantes Cedex \\ (*) I.N.R.A., Laboratoire de Chimie Biologique, INA.PG, Centre de Grignon, F 78850 Thiverval-Grignon
}

Additional key words : Cell-wall mutation. p-coumaric acid, ferulic acid, hemicelluloses, celluloses, straw.

Etude d'un mutant à tige cassante de riz, Oryza sativa $L$. ; préparation de fractions de lignine et caractérisation des acides phénoliques et polyosides associés.

\begin{abstract}
On a caractérisé par analyses chimiques des fractions de lignine, les acides p-coumariques, féruliques et les polyosides associés, qui ont été isolés de la paille d'un cultivar de riz « Balilla 28 » et d'un de ses mutants à tige cassante. Des différences significatives ont été observées entre les deux types de riz pour les teneurs en lignines (Klason, au bromure d'acétyle et insoluble dans les acides), en esters et ethers d'acides phénoliques, en polyosides hemicellulosiques et cellulosiques ainsi que pour les rendements d'extraction des fractions de lignine et d'hydrolyse par des polyosidases. Le caractère cassant des tiges du mutant ne peut donc pas être simplement mis en relation avec les variations de composition chimique d'un constituant pariétal particulier. Ces résultats sont discutés en fonction des variations corrélatives de composition chimique des parois cellulaires et d'hétérogénéité de composition monomérique des lignines.
\end{abstract}

Mots clés additionnels : Mutation de la paroi cellulaire, acide p-coumarique, acide férulique, hemicelluloses, celluloses, paille.

\section{INTRODUCTION}

The use of mutants is now a classical approach for study of biosynthetic pathways in plants: it is of particular interest when lignification processes are concerned since the influence of lignification pattern on properties of lignocellulosic materials can be analyzed by comparison of different genotypes.

a) Present address (US) : $R$ and D Section, New Central Jute Mills, PO Budge Budge, 743319 India.

b) To whom correspondence should be send.
Rice, Oryza sativa L., is the third gramineous species after maize, Zea mays L., (JORGENSEN, 1931) and sorghum, Sorghum bicolor L., (PORTER et al., 1978) from which a mutant has been obtained at the level of the lignification process.

The mutant of rice has been obtained by gamma irradiation of the normal rice cultivar "Balilla 28" at the I.N.R.A. Plant Breeding Station of Montpellier (France) and is characterized by a brittleness of the culm appearing only in mature plants without any effect on the high resistance to lodging. The mutant exhibited higher contents of Klason lignin and of hot- 
alkali soluble compounds and a lower proportion of $\alpha$-cellulose than the normal cultivar (DOAT \& MARIE, 1977). In agreement with these results concerning the rough chemical and mechanical properties of these rices, we also found that the mutant rice stem (culm) is richer in cell-wall bound $p$-coumaric esters while wall-linked ferulic ester content was similar in both mutant and normal rice (MONTIES et al., 1981). In addition, the extent of degradation of normal rice straw by both commercial crude cellulases and rumen juice liquor was wider than that of mutant one.

As these last differences may be related to variations in cell wall phenolics but also in polysaccharide composition, a reexamination of the cell wall constituents of normal and mutant rice straws has been undertaken. We report here results concerning the phenolic and polysaccharide compositions of three different lignin fractions and of the corresponding cell walls for straws. Structural characterization of polysaccharide fractions will be published elsewhere. Only nitrobenzene oxidation was used here for monomeric characterization of the rice lignin fractions; results concerning the non-condensed monomeric units obtained in these conditions are thus discussed in relation with the phenomenon of lignin heterogeneity (MONTIES \& LAPIERRE, 1981; MONTIES, 1986).

\section{MATERIAL AND METHODS}

Rices, "Balilla 28" and its corresponding brittlestem mutant, were grown at Montpellier in the rice plantations of I.N.R.A. using standard conditions of cultivation with N-P-K fertilization corresponding to 152-168-120 units respectively (MARIE, 1984 ; MARIE et al., 1985). They were harvested at grain maturity. Straw was air-dried. Leaves were removed from the culm (stems) before rough grinding with a Culliatti hammer mill. The powder was then ball-milled with a stainless Dangoumeau to obtain a final particle size less than $0.1 \mathrm{~mm}$.

\section{A. Determination of cell-wall phenolics}

Extractives were removed from the rough powder by three successive soxhlet extractions with tolueneethanol mixture $(1 / 1 \mathrm{vol})$, ethanol and water. The cell wall residue "parietal residue : PR" was then freezedried.

\section{B. Lignin determination}

Lignin was estimated by three different methods. After $5 \%$ sulfuric acid prehydrolysis of the PR, acidinsoluble lignin (AIL) was obtained by $72 \%$ sulfuric acid hydrolysis followed by post-hydrolysis in $5 \%$ sulfuric acid as previously discussed (MONTIES, 1984). Klason lignin (KL) was obtained by the same procedure but without prehydrolysis. Acetyl-bromide lignin was estimated according to the procedure of JOHNSON et al. (1961) with slight modifications : $25 \mathrm{mg}$ of $\mathrm{PR}$ were treated with $10 \mathrm{ml}$ of reagent according to JOHNSON but only $1 \mathrm{ml}$ of the solution was analyzed, after dilution in $25 \mathrm{ml}$ with glacial acetic acid, following the standard procedure of UV absorbance at $280 \mathrm{~nm}$. A calibration curve, corresponding to 5 to $15 \mathrm{mg}$ of guaiacol (2-methoxy phenol, SIGMA puriss.) was used for calculation and standardisation of the results. Data were expressed with reference to the Klason lignin as follows: a milled straw lignin preparation of known Klason lignin content, was submitted to acetyl-bromide solubilization, compared to the guaiacol standard curve, then a coefficient was calculated for conversion of guaiacol equivalent value (GEV) to Klason lignin equivalent (KLE).

\section{Phenolic ester and phenolic ether determination}

Cell wall bound esters and ethers of phenolic acids were estimated by a combination of alkaline and acid hydrolyses. Esters were first hydrolysed with $2 \mathrm{~N}$ $\mathrm{NaOH}, 20 \mathrm{ml}$ for $100 \mathrm{mg}$ of parietal residue, during $2 \mathrm{~h}$ at $35 \pm 1{ }^{\circ} \mathrm{C}$ with magnetic agitation under nitrogen. The insoluble residue obtained after saponification was recovered by filtration and submitted to a second alkaline hydrolysis for exhaustive hydrolysis of esters. The insoluble final residue, saponification residue (RS), recovered by filtration was washed with water, until about neutrality ( $\mathrm{pH} \mathrm{6-7),} \mathrm{then} \mathrm{with} 0.1 \mathrm{~N} \mathrm{HCl}$ and used, without drying, for estimation of ethers. Ethers were hydrolysed with $0.1 \mathrm{~N} \mathrm{HCl}$ in dioxanewater mixture, $10 \mathrm{ml}$ for the total RS corresponding to $100 \mathrm{mg}$ of $\mathrm{RP}$, during $4 \mathrm{~h}$ in a sealed $20 \mathrm{ml}$ tube at $100{ }^{\circ} \mathrm{C}$. Phenolic acids corresponding to the cell-wall ethers were recovered from the acidolysis mixture by ethylether extraction as described by SCALBERT et al. (1985). Phenolic acids corresponding to the cell wall esters were similarly isolated by diethylether extraction after acidification of the soluble extracts and washings recovered during the $\mathrm{RS}$ preparation. Phenolic acids were, in each case, analyzed by HPLC. After drying on $\mathrm{Na}_{2} \mathrm{SO}_{4}$, diethylether extracts were concentrated under vacuum and recovered with methanol containing 1,2,3-trimethoxybenzaldehyde (Aldrich, puriss) at the concentration of 0.5 or $1.0 \mu \mathrm{g} / \mu \mathrm{l}$ as internal standard according to the concentration of the samples. Phenolic acids were separated by reverse phase HPLC with a Resolve C18-5 $\mu$ Waters column with a mixture of methanol-water (30-70 vol) containing $1 \%$ of acetic acid either in isocratic conditions at a flow rate of $1 \mathrm{ml} \cdot \mathrm{mn}^{-1}$ or by gradient chromatography as described previously (MONTIES et al., 1981 ; SCALBERT et al., 1985). Purity of the transand $c i s$-isomers of $p$-coumaric and of ferulic acids was controlled by cochromatography, by on-line recording of the UV-spectra of the products during the elution with a diode array detector (Hewlett-Packard 1040 A) and comparison of the position and the ratio of the maximum and minimum of absorbance between 250 to $450 \mathrm{~nm}$. Cis-isomers were only observed when exposure of samples to sunlight was not carefully controlled.

\section{Fractionation of straw lignin}

Finely ground parietal residue was ultraground in a Seibtecknik vibratory mill and lignin was isolated into three fractions LM, LE and LR according to 
LAPIERRE et al. (1982) and SCALBERT et al. (1985). The fractionation procedure is shown in table 1 . Conditions of ultragrinding and extraction chosen for fractionation of poplar wood were used without modification for straw. Fractionation was repeated twice giving very reproducible yields. The monomeric composition of the non-condensed monomeric units of these lignin fractions was characterized by nitrobenzene oxidation and analysis of the resulting aromatic aldehydes by HPLC as previously reported (MONTIES et al., 1981a ; SCALBERT et al., 1985).

\section{E. Carbohydrate analysis}

Cell wall residue polysaccharides were hydrolyzed according to SAEMAN et al. (1954) while carbohydrate moieties associated with lignin fractions LM, LE and LR were hydrolyzed with $2 \mathrm{~N}$ trifluoroacetic acid (TFA) for $75 \mathrm{mn}$ at $125^{\circ} \mathrm{C}$ (ALBERSHEIM et al., 1967). Liberated neutral sugars were analyzed as their alditol-acetate derivatives (SAWARDEKER et al., 1965) by $\mathrm{GC}$ on a glass column $(180 \times 0.2 \mathrm{~cm})$ packed with $3 \%$ SP 2340 coated on Supelcoport (100-120 mesh) at $225{ }^{\circ} \mathrm{C}$ (BRILlouet et al., 1982).

The determination of acid-insoluble lignin after $5 \%$ sulfuric acid prehydrolysis allows, also, the estimation of two rough polysaccharide fractions which are hydrolyzed with $5 \%$ and $72 \%$ sulfuric acid respectively. These two fractions had been described previously in the case of poplar wood and of wheat straw (MONTIES, 1984), as "readily acid hydrolysable and solubilized products" (PAS : "produits aisément solubilisables" in French : MONTIES, 1984) and as "poorly acid hydrolysable and solubilized products" (PDS : "produits difficilement solubilisables" in French: MONTIES, 1984). The content of PAS and PDS has been calculated here, as previously, by difference between the content in ash (A), acid insoluble lignin (LAI), and lignocellulose recovered after prehydrolysis (LC) by the relations :

$\mathrm{PAS}=\mathrm{PR}-\mathrm{LC}$ and PDS $=\mathrm{LC}-\mathrm{AIL}-\mathrm{A}$. $3 \mathrm{~h}$.

Ash was weighed after mineralization at $550^{\circ} \mathrm{C}$ for

\section{RESULTS AND DISCUSSION}

The chemical composition of the parietal residue from mutant and normal rice culms is given in table 2 .

Whatever the analytical procedure, the lignin content of the mutant was, in each case, significantly higher than that from the normal. Relative lignin contents appeared, however, different depending on the method used. In accord with the results previously reported on poplar wood and wheat straw (MONTIES, 1984), the Klason lignin content was significantly higher than the acid-insoluble lignin content. As previously discussed, KL content is probably overestimated due to condensation with other cell wall components (DILL et al., 1984 ; MATSUMOTO et al., 1984) while, on the other hand, AIL content is certainly an underestimation of total lignin because of the loss of acid-soluble monomeric products and

\section{TABLE 1}

Scheme for isolation of lignin fractions: milled straw lignin (LM), enzyme lignin ( $L E)$ and residual lignin ( $L R)$ from culm of normal and mutant rices.

Protocole d'isolement des fractions de lignine: lignine de paille moulue (LM), lignine par enzyme (LE) et lignine résiduelle (LR) isolées des chaumes de riz normal et mutant.

$$
\begin{gathered}
\text { Finely ground cell wall } \\
\text { Soxlhet extraction } \\
\text { Ultragrinding }(48 \mathrm{~h}) \\
\text { Ist dioxane-water }(9 / 1 \text { vol) extraction } \rightarrow \text { LM } \\
! \\
\text { Two successive cellulase hydrolyses } \\
\text { (Rough Trichoderma viride enzyme) } \\
\text { Filtration and washing of insoluble residue } \\
! \rightarrow \text { (UP) } \\
\text { 2nd dioxane-water }(9 / 1 \text { vol) extraction } \rightarrow \text { LE } \\
\text { Washing and drying } \\
\text { Ultragrinding (48 h) } \\
\text { 3rd dioxane-water }(9 / 1 \text { vol) extraction } \rightarrow \text { LR } \\
\text { Washing and drying } \rightarrow \text { Final residue (FR) }
\end{gathered}
$$

* Filtrate and washing were pooled and dialyzed against water, undialyzable products from enzymatic hydrolysis were recovered by

\begin{tabular}{|c|c|c|c|c|c|c|}
\hline \multirow{2}{*}{ Fractions } & \multicolumn{3}{|c|}{ Lignins } & \multicolumn{2}{|c|}{$\begin{array}{l}\text { Acid-hydro- } \\
\text { lysable products }\end{array}$} & \multirow{2}{*}{$\begin{array}{l}\text { Ash } \\
550^{\circ} \\
A^{*}\end{array}$} \\
\hline & $\begin{array}{c}\text { Klason } \\
\mathrm{KL}^{*}\end{array}$ & $\begin{array}{l}\text { Acetyl- } \\
\text { bromide in } \\
\text { KEL* }^{*}\end{array}$ & $\begin{array}{l}\text { Acid- } \\
\text { nsoluble } \\
\text { AIL* }\end{array}$ & $\begin{array}{c}5 \% \\
\mathrm{SO}_{4} \mathrm{H}_{2} \\
\mathrm{PAS}^{*}\end{array}$ & $\begin{array}{c}72 \% \\
\mathrm{SO}_{4} \mathrm{H}_{2} \\
\mathrm{PDS}^{*}\end{array}$ & \\
\hline Normal & 12.5 & 9.9 & 9.3 & 38.5 & 46.2 & 2.8 \\
\hline Mutant & 14.9 & 12.6 & 11.4 & 43.5 & 37.3 & 4.3 \\
\hline
\end{tabular}
freeze drying : (UP).

* Après filtration, réunion des lavages et dialyse contre de l'eau, les produits non dialysables formés après hydrolyse enzymatique sont récupérés par lyophilisation : (UP).

\section{TABLE 2}

Composition of cell wall residues from culm of normal and mutant rice.

Contents in per cent of dry parietal residue $(R P)^{*}$, calculation procedure of " readily sulfuric acid solubilizable products " (PAS) and «poorly sulfuric acid solubilizable products » (PDS) given in chapter $I I$.

Composition des résidus pariétaux des chaumes de riz normal et mutant.

Teneur en pourcentage de la matière sèche du résidu pariétal (RP)*, méthodes de calcul des " produits aisément solubilisables par l'acide sulfurique » (PAS) et des « produits difficilement solubilisables par l'acide sulfurique » (PDS), décrites dans le Chapitre II.

* Abbreviations and definitions in chapter II.

oligomeric fractions. The acetyl-bromide lignin $(\mathrm{KEL})$, given in table 1, was obtained after standardization with a milled straw lignin sample as previously suggested by JOHNSON et al. (1961) or by MORRISON (1972). Obviously, the KEL value allows a direct comparison of the results obtained by these different methods, but, even after these calculations, KEL value has to be considered only as a relative one due to possible variations of specific UV absorbance 
between lignin fractions, to systematic occurrence of non-lignin components such as polysaccharide in lignin preparations and finally to uncertainties in $\mathrm{KL}$ determination discussed before. Acetyl-bromide determination of lignin is usually considered as an estimation of total lignin because parietal residue is solubilized without any pretreatment. The fact that, in table 2, the acetyl-bromide lignin value (KEL) is nearer the acid-insoluble lignin (AIL) than the Klason lignin $(\mathrm{KL})$ value is thus unexpected. As, up to now, no detailed UV characterization of rice-straw lignin fractions are available, these results cannot be discussed more precisely.

During the determination of the acid-insoluble lignin, it is worthwile to estimate the weight losses after treatment by $5 \%$ and by $72 \%$ sulfuric acid. The loss of dry matter after prehydrolysis of the cell wall residue may be considered roughly as the amount of polysaccharides which are readily hydrolyzed by dilute acid, i.e. arabino-glucuronoxylans in the case of grass straw (JoselEAU, 1980). The hydrolysis step by $72 \%$ sulfuric acid removes essentially the cellulose and xylan moieties which resisted the prehydrolysis treatment. From table 2, the weight loss after prehydrolysis was higher for the mutant than for the normal rice. In contrast, the decrease of dry matter on $72 \%$ sulfuric acid hydrolysis was lower for the mutant rice than for the normal one, in agreement with previous results (MONTIES et al., 1981). Indeed the mutant rice stem was richer in hemicellulose polymers and poorer in cellulose than the normal one, which contained more cellulose and a lower proportion of hemicelluloses. This preliminary conclusion was sustained by the relative composition of monosaccharide constituents of the cell wall polymers given in table 3 . The cell wall from mutant rice contained more xylose and arabinose than that from normal one : these two sugars are constitutive of the hemicellulosic fraction of grass straw. On the other hand, glucose, originating mainly from cellulosic glucans, occurs in greater relative quantity in the cell wall from normal rice stem. Using other rough methods, DOAT \& MARIE (1971) reported in agreement with our results that the mutant of rice had a higher hot alkaline extract, hemicellulosic products, and a lower $\alpha$ cellulose content.

Table 3 also shows that the xylose/arabinose ratio, which is indicative of the degree of branching of xylan chains, was higher in the mutant (4.8) than in normal rice $(4.0)$. Therefore hemicelluloses from the brittleculm mutant seemed more linear than in the normal

\section{TABLE 3}

Relative composition of polysaccharide sugar constituents in the cell wall residue from culm of normal and mutant rice.

Composition relative, exprimée en oses, des polyosides du résidu pariétal du chaume des riz normal et mulant.

\begin{tabular}{lcccccc}
\hline \hline Sugar & Glucose & \multicolumn{2}{c}{ Xylose } & \multicolumn{4}{c}{ Arabinose Galactose Mannose Rhamnose } \\
\hline Normal & 70.4 & 22.5 & 5.6 & 1.5 & $\operatorname{tr}^{*}$ & $\operatorname{tr}^{*}$ \\
Mutant & 59.7 & 31.4 & 6.5 & 2.0 & 0.2 & 0.1 \\
\hline \hline
\end{tabular}

* $\operatorname{tr}$ : traces about 0.02 to 0.05 . one. However, this observation needs to be confirmed by methylation analysis of cell wall polysaccharides.

Results concerning the characterization of phenolic acids bound to the stem cell walls are shown in table 4 and figure 1 . In addition to the confirmation of the occurrence of $p$-coumaric and ferulic esters in rice cell wall, table 4 shows also the occurrence of ethers of the same phenolic acids. Ethers of $p$-coumaric and of

\section{TABLE 4}

Phenolic acids bound to the stem cell wall of the mutant and normal rice. Contents are given in per cent of dry $R P^{*}$. Acides phénoliques liés au résidu pariétal des riz normal et mutant. Teneurs en pourcentage de la matière sèche du RP sec.

\begin{tabular}{|c|c|c|c|c|c|}
\hline & \multirow{2}{*}{$\begin{array}{l}\text { Saponi- } \\
\text { fication } \\
\text { residue } \\
(\mathrm{RS})^{*}\end{array}$} & \multicolumn{2}{|c|}{$p$-coumaric acid } & \multicolumn{2}{|c|}{ ferulic acid } \\
\hline & & esters & ethers & esters & ethers \\
\hline Normal & 65 & 0.83 & 0.11 & 0.24 & 0.20 \\
\hline Mutant & 55 & 1.19 & 0.11 & 0.26 & 0.08 \\
\hline
\end{tabular}

* Abbreviations in chapter II.
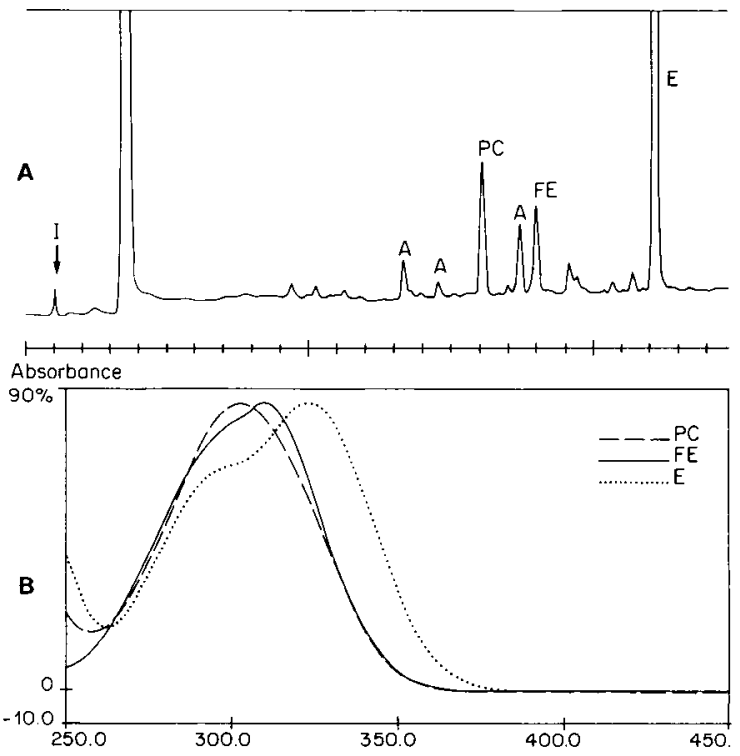

Figure 1

Isolation and characterization of the ethers of phenolic acids associated with cell-wall preparations of rice stem. Results corresponding to normal rice; identical qualitative results have been obtained with the mutant.

A) High-pressure liquid chromatography separation of phenolic acid solubilized after acidolysis following exhaustive alkaline hydrolysis : $P C=\mathrm{p}$-coumaric acid (trans form), $F E=$ ferulic acid (trans form), $A=$ acidolysis products, $E=$ internal standard : 3 , 4, 5-trimethoxycinnamaldehyde.

B) Absorption spectra of phenolic acids isolated from rice stem. - Séparation et caractérisation des éthers d'acides phénoliques présents dans les préparations de parois cellulaires de tige de $R_{17}$. Résultats correspondant au riz normal; des résultats qualitativement identiques ont été obtenus avec le mutant.

A) Séparation par chromatographie liquide haute pression des acides phénoliques libérés par acidolyse après hydrolyse alcaline exhaustive: $P C=$ acide $\mathrm{p}$-coumarique, $F E=$ acide férulique, $A=$ produits d'acidolyse, $E=$ étalon interne $13,4,5$-triméthoxycinnamaldéhyde).

B) Spectres d'absorption des produits isolés de tige de riz. 
ferulic acid bound to rice cell wall are reported here for the first time; this result is in line with the occurrence of the same type of ethers in wheat straw cell wall, as recently reported by SCALBERT et al. (1985). In the case of the two rice cultivars reported here, the trans-isomers of $p$-coumaric and ferulic acids were characterized only by cochromatography and on-line UV-spectrophotometry during elution.

Significant differences in the distribution of cell wall-linked phenolic acids are also shown in table 4 . While the amount of ferulic esters was the same in both rices, the amount of esters of $p$-coumaric acid was increased in the mutant, which is in complete agreement with data reported earlier by MONTIES et al. (1981); the $p$-coumaric to ferulic esters ratio was, however, higher than those previously reported. The opposite figure was observed for the ethers; the amount of $p$-coumaric ethers was the same in both rices while ethers of ferulic acid were reduced in the mutant. As, however, the data reported here concern only one sample of rice, these differences in distribution between ethers and esters require confirmation with other samples of rice grown in different conditions.

In addition, table 4 shows a higher yield of recovery of saponification residue (RS) in the case of the normal rice. Recovery yields of RS could be related to the higher content of mutant rice cell wall in hemicellulosic glucuronoarabinoxylans : indeed most of the xylan, and also part of the lignin, underwent solubilization under saponification conditions. These last observations were well correlated with PAS data obtained from acid prehydrolysis reported in table 2 and 3 .

Table 5 summarizes the fractionation results of lignin from rice culm following the procedure of table 1; three lignin fractions (milled straw lignin, enzyme lignin and residual lignin) were prepared. As cell wall polymers may be associated with the lignin fractions, recovery yields must be compared with caution. The LM fractions were obtained in the same yield for both rices while yields of LE and LR have been always found higher for the normal than for the mutant, which is surprising since the mutant culm is more lignified than the normal one. The most pro-

\section{TABLE 5}

Isolation yields of lignins $L M, L E, L R$ and of corresponding residues during fractionation of stem cell wall of mutant and normal rices.

Rendements d'isolement des fractions de lignine $L M, L E, L R$ et des résidus correspondants obtenus à partir du résidu pariétal de tiges de riz normal et mutant.

\begin{tabular}{lcccccc}
\hline \hline & \multicolumn{4}{c}{ Lignin fractions } & $\begin{array}{c}\text { Final } \\
\text { residue }\end{array}$ & $\begin{array}{c}\text { Undialysed } \\
\text { products } \\
\text { UP }\end{array}$ \\
\cline { 2 - 5 } & LM & LE & LR & $\begin{array}{c}\text { Total } \\
(\% \mathrm{KL})\end{array}$ & FR & \\
\hline Normal & 1.4 & 3.5 & 1.3 & 49.6 & 17.0 & 3.7 \\
Mutant & 1.4 & 2.5 & 0.6 & 30.2 & 8.0 & 12.5 \\
\hline \hline
\end{tabular}

Abbreviations in chapter II according to table 1, yields in per cent of dried parietal residue (RP).

Abréviations selon chapitre II et tableau 1, rendements en pourcentage de la matière sèche du résidu pariétal (RP). minent difference between the two rices was the greater sensitivity of the mutant cell walls to Trichoderma viride cellulase hydrolysis compared to the normal one. This differential sensitivity is clearly shown in table 5 by the higher yield in undialyzable products (UP) for the mutant and by the corresponding lower yield in final residue (FR) which was about half that of the normal one. These data were rather unexpected since the more lignified culm of mutant was supposed to be more resistant to enzyme hydrolysis than the normal one. In the previous study of MONTIES et al. (1981), no significant difference was found, after cellulase hydrolysis, between the normal and the mutant rice. As, however, commercial Oxyporus cellulase preparation was used in place of commercial Trichoderma cellulase used in the present fractionations and as enzymatic treatment of $24 \mathrm{~h}$ was chosen in place of repeated and extensive cellulase hydrolysis used in the present procedure (table 4), these differences of yield may be explained by the well established structural and kinetic differences occurring between commercial cellulase preparations (AZUMA et al., 1983).

Due to the relatively low quantities of LR fractions isolated from the mutant, only LM and LE lignin fractions were characterized here.

Significant differences in monomeric composition of LM and LE fractions were observed by nitrobenzene oxidation as shown in table 6 . In both cases, the syringaldehyde to vanillin ratio and the $p$ hydroxybenzaldehyde to vanillin ratio were higher for the mutant than for normal rice. Similar differences have previously been reported for these two ratios (MONTIES et al., 1981a). Nevertheless, no significant differences in monomeric composition could be observed in table 6 between LM and LE fractions isolated from both type of rice. Even if analysis of phenolic aldehydes obtained by nitrobenzene oxidation only allows the characterization of the non-condensed monomeric units of lignin, these last results clearly show that monomeric heterogeneity was not observed between lignin fractions isolated from the two rice straws. Recently the same results were reported by SCALBERT et al. (1986) who were

\section{TABLE 6}

Monomeric composition of $L M$ and $L E$ lignin fractions isolated from culm of normal and mutant rices as shown by nitrobenzene oxidation and separation of non-condensed corresponding monomeric products.

Composition monomérique des fractions de lignine $L M$ et $L E$ isolées de chaume de riz normal et mutant, détermination par oxyda tion au nitrobenzène et séparation des produits monomères correspondant aux unités non condensées.

\begin{tabular}{|c|c|c|c|c|}
\hline \multirow{2}{*}{\multicolumn{2}{|c|}{$\begin{array}{l}\text { Rice lignin } \\
\text { fractions }\end{array}$}} & \multirow{2}{*}{ Vanillin } & \multirow{2}{*}{$\frac{\mathrm{p} \text {-OH-benzaldehyde }}{\text { Vanillin }}$} & \multirow{2}{*}{$\frac{\text { syringaldehyde }}{\text { Vanillin }}$} \\
\hline & & & & \\
\hline \multirow{2}{*}{ LM } & Normal & 3.5 & 0.43 & 1.14 \\
\hline & Mutant & 3.0 & 0.53 & 1.37 \\
\hline & Normal & 3.2 & 0.44 & 1.16 \\
\hline & Mutant & 4.9 & 0.49 & 1.27 \\
\hline
\end{tabular}

Yield in per cent of corresponding dry lignin fraction.

Rendement en pourcentage de la masse des fractions de lignine. 
unable to show lignin heterogeneity between fractions isolated from wheat straw. This inability to detect heterogeneity of monomeric composition in grass straw lignins is rather surprising when considered with reference to evidence and confirmations of the occurrence of such heterogeneity in the case of angiosperm woods such as normal and reaction wood of poplars (LAPIERRE \& MONTIES, 1982 ; LAPIERRE et al., 1982). Furthermore, monomeric heterogeneity between lignin fractions isolated from oak woods has recently been found by MONTIES \& LAPIERRE (in preparation), confirming the occurrence of lignin heterogeneity in angiosperm woods.

The inability to observe this phenomenon in the case of grass straws may result, for example, from the fact that the cytological and cytochemical structures of culm is far more complex than those of wood. The rough fractionation procedure shown in table 1 would thus allow the isolation of heterogeneous fractions of lignin when applied to samples containing a small number of cellular types, as in the case of wood xylem, but not when applied to more complex mixture of tissues, such as in the culm of grass straws. Another, but less likely, hypothesis is that the fractionation procedure chosen for woods is not well fitted for straws and requires specific adaptation.

The chemical composition of the polysaccharides associated with the rice lignin fractions is shown in table 7. Clearly, in each case, lignin preparations were mainly associated with arabinoxylans. No significant differences were observed between preparations isolated from normal and from mutant rice straws. The arabinose to xylose ratio was significantly higher, in each rice, in LE than in LM ; however in LR, this ratio was nearer of those in LE than those in LM. These differences probably depend on cellulase treatment and cannot be used directly for discussion on the structure of lignin polysaccharide associations.

\section{CONCLUSION}

The results presented in this study clearly show that the brittle-culm mutation of rice not only changes, quantitatively and qualitatively, the phenolic fraction (lignin and bound phenolic acid) of the culm cell wall but also the polysaccharides (hemicellulosic arabinoxylan and cellulose). As variations in many different chemical factors are associated with the brittle-culm character of the mutant, it seems difficult to correlate specific changes in properties of the lignocellulosic material, such as in vitro digestibility or mechanical properties, with only one chemical factor such as lignification. A strong correlation between lignin and hemicellulose concentrations has been reported in ten varieties of temperate grasses by MORRISON (1980); the varieties with higher lignin concentration showed higher linear hemicellulose content. The differences reported here between the mutant and the normal cultivar of rice agree with these observations but perhaps fortuitously ; it would thus be interesting to search if the same correlation is also found in other lignin mutants of Gramineae, such as corn and sorghum.

Furthermore, when the results reported here are compared with those of the two previous studies

\section{TABLE 7}

Relative composition of the polysaccharide associated with the lignin fraction $L M, L E, L R$ isolated from culm of normal and from mutant rice. Fractions $L M, L E, L R$ corresponding to table 1 for normal $(N)$ and mutant $(M)$ rice.

Composition relative, exprimée en oses, des polyosides associés aux fractions de lignine $L M, L E, L R$ isolées du chaume des riz normal et mulant. Fractions $L M, L E, L R$ correspondant au tableau 1 pour les riz normal et mutant.

\begin{tabular}{|c|c|c|c|c|c|c|}
\hline & Glucose & Xylose & Arabinose & Galactose & Mannose & Rhamnose \\
\hline \multirow{2}{*}{ LM } & 5.5 & 79.6 & 13.2 & 1.1 & 0.1 & 0.1 \\
\hline & 5.2 & 80.2 & 13.2 & 1.1 & 0.1 & 0.3 \\
\hline \multirow{2}{*}{ LE } & 6.7 & 75.3 & 17.0 & 0.8 & 0.1 & $\operatorname{tr}$ \\
\hline & 4.6 & 78.3 & 16.3 & 0.5 & 0.1 & $\mathrm{tr}$ \\
\hline \multirow{2}{*}{ LR } & 5.7 & 77.0 & 15.0 & 1.7 & 0.4 & $\mathrm{tr}$ \\
\hline & 6.5 & 74.8 & 15.7 & 2.2 & 0.4 & $\mathrm{tr}$ \\
\hline
\end{tabular}

tr : trace less than 0.05

published by DOAT \& MARIE (1977) and by MONTIES et al. (1981a), a very good agreement appears which may indicate that strong genetic control occurs during the biosynthesis of the plant cell wall. The same type of conclusion has been suggested previously from comparison of the chemical composition of wheat straw harvested after very different conditions of growth (BAYET \& MONTIES, 1977). The occurrence of such a strong genetic control may be of great importance in research programs concerning the biodegradability of the gramineous cell wall applied for example to pathogen resistance or to increase of digestibility by animals.

In this case, very careful studies of the correlations between variations in the fine chemical composition of plant cell wall would be required; correlations between variations in lignin and hemicellulose have been recalled previously. The fact that the rough composition of the cell wall polysaccharide may change without significant variation in the content of associated ferulic esters and $p$-coumaric ethers is a second example of such fine variation ; the occurrence of a possible genetic control remains to be established in this last case however. Furthermore, subtle changes may also occur after modification of the lignification characters at the level of not only the content and the monomeric composition of total lignin but also the extractibility and composition of lignin fractions. Much work remains to be done particularly to characterize variations in the lignin fractions easily solubilized during mild alkaline and acid treatment of straws. Wheat-lignin-labelling experiments by incorporation of $\mathrm{U}-{ }^{14} \mathrm{C}$-phenylalanine have, indeed, shown quantitative and qualitative differences of labelling between lignin fractions (BAYET, 1980; AGOSIN et al., 1986). Lignin heterogeneity not observed here in the case of rice and previously in the case of wheat may thus be shown using different analytical methods.

In conclusion many comparative studies of the fine chemical composition of the cell wall remains to be done not only with rice but also with other Gramineae such as wheat, and with "mutants" for lignification ; such studies may provide more exhaustive expla- 
nations on the molecular mechanisms involved in the physico-chemical properties of lignocellulosic materials.

Reçu le 2 septembre 1985. Accepté le 30 octobre 1985.

\section{ACKNOWLEDGMENT}

Thanks are due to R. MARIE (Station Amélioration des Plantes, I.N.R.A., F 34000 Montpellier) for the cultivation, the preparation of the sample of straw and for his constant interest.

\section{REFERENCES BIBLIOGRAPHIQUES}

Agosin E., Monties B., Odier E., 1986. Structural changes in wheat straw lignin component during decay by lignin degrading white rot fungi in relation to improvement of digestibility for ruminants. $J$. Sci. Food Agric. (in press).

Albersheim P., Nevins D. J., English P. D., Karr A., 1967. A method for the analysis of sugars in plant cell wall polysaccharides by gas-liquid chromatography. Carbohyd. Res., 5, 340-345.

Azuma J. I., Tanaka F., Koshijima T., 1983. Enzymatic saccharification of woody plants. I. Effects of expanded softening and ball-milling on enzymatic saccharification. Wood Res., 69, 22-35.

Bayet F., 1980. Etude de la lignin' et des acides phénoliques de la paille de blé. Thèse Ing. Doct. INA. PG., I.N.R.A. éd., 133 p.

Bayet F., Monties B., 1977. Characterization of wheat straw lignin in relation to different mineral fertilization conditions. HoppeSeyler's Z. Physiol. Chem., 358, 1177-1178.

Brillouet J. M., Joseleau J. P., Utille J. P., Lelièvre D., 1982 Isolation, purification and characterization of complex heteroxylans from industrial wheat brans. J. Agr. Food Chem., 30, 488-495.

Dill I., Salnikov J., Kraepelin G., 1984. Hydroxyproline-rich protein material in wood and lignin of Fagus sylvatica. Appl. Envi. ron. Microbiol., 48, 1259-1261.

Doat J., Marie R., 1977. Analyse d'un mutant tige cassante radioinduit chez le riz, Oryza sativa L.. Ann. Amelior. Plantes, 27, 705 715 .

Johnson D. B., Moore W. E., Zank L. C., 1961. The spectroscopic determination of lignin in small wood samples. Tappi, 44, 793-798.

Jorgensen L. R., 1931. Brown midribs in maize and its linkage relations. J. Am. Soc, Agron., 23, 549-556.

Joseleau J. P., 1980. Les hemicelluloses, 87-121. In : B. MontIEs : "Les polymères végétaux : polymères pariétaux et alimentaires non azotés », Gauthier-Villars ed., Paris, 345 p.

Lapierre C., Lallemand J. Y., Monties B., 1982a. Evidence of poplar lignin heterogeneity by combination of ${ }^{13} \mathrm{C}$ and ${ }^{1} \mathrm{H}$ NMR spectroscopy. Holzforschung, 36, 275-282.

Lapierre C., Monties B., 1982b. Etude de la lignite de bois de réaction du peuplier. Comm. Colloque Sciences et Industries du Bois (20-22 septembre, Grenoble, France), 1, 135-145.

Marie R., 1984. «Et ... si on parlait du riz ? ». Bulletin Semences, 89. 41,44 .
Marie R., Guillard M., Seguy J. L., 1985. La rizière expérimentale de l'I.N.R.A., 1985. Agriculteur Provençal, 96, 8 p.

Matsumoto Y., Ishizu A., Nakano J., 1984. Residual lignin in Klason lignin. J. Wood Sci. Technol., 4, 321-330.

Monties B., Mestres C., Baghdadi K., 1981 $a$. Chemical and physical properties of a brittle culm lignin rich mutant of rice. The Ekman Days 1981. (Int. Symp. on Wood and Pulping Chemistry, Stockholm, June 9-12), 5, V40-V43.

Monties B., Lapierre C., 1981b. Données récentes sur l'hétérogénéité des lignites. Physiol. Vég., 19, 327-348.

Monties B., 1984. Dosage de la lignine insoluble en milieu acide : influence du prétraitement par hydrolyse acide sur la lignine Klason de bois et de paille. Agronomie, 4, 387-392.

Van Sumere C., Monties B., 1986. Recent advances in lignin heterogeneity. In : 'The Biochemistry of Plant Phenolics', (Ann. Proc. Phytochem. Europ.), 25, 161-181.

Morrison I. M., 1972. A semi-micro method for the determination of lignin and its use in predicting the digestibility of forage crops. $J$. Sci. Fd. Agric., 23, 455-463.

Morrison I. M., 1980. Changes in the lignin and hemicellulose concentration of ten varieties of temperate grasses with increasing maturity. Grass and Forage Sci., 35, 287-293.

Porter K. S., Axtell J. D., Lechtenberg V. L., Collenbrander V. F., 1978. Phenotype, fiber composition and in vitro dry matter disappearance of chemically induced brown midrib (bmr) mutants of sorghum. Crop Sci., 18, 205-208.

Saeman J. F., Moore W. E., Mitchell R. L., Millet M. A., 1954 Techniques for the determination of pulp constituents by quantitative paper chromatography. Tappi, 37, 336-339.

Sawardeker J. S., Sloneker J. H., Jeanes A., 1965. Quantitative determination of monosaccharides as their alditolacetate by gaschromatography. Anal. Chem., 37, 1602-1604.

Scalbert A., Monties B., Lallemand J. Y., Guittet E., Rolando C., 1985. Ether linkage between phenolic acids and lignin fractions from wheat straw. Phytochemistry, 24, 1359-1362.

Scalbert A., Monties B., Guittet E., Lallemand Y., 1986. Comparison of wheat straw lignin fractions. I. Chemical and spectroscopic characterization. Holzforschung (in press). 